\title{
History of cyclodextrin-based polymers in food and pharmacy: a review
}

\author{
Max Petitjean ${ }^{1}$ - Iñigo X. García-Zubiri ${ }^{2}$ José Ramón Isasi ${ }^{1}$ (I)
}

Received: 27 March 2021 / Accepted: 13 April 2021 / Published online: 23 April 2021

(c) The Author(s), under exclusive licence to Springer Nature Switzerland AG 2021

\begin{abstract}
Cyclodextrins are glucose macrocycles whose inclusional capabilities towards non-polar solutes can be modulated with the help of other macrostructures. The incorporation of cyclodextrin moieties into larger structures produces five types of new materials: crosslinked networks, functionalized chains, amphiphilic cyclodextrins, polyrotaxanes and nanocomposites. This review presents crosslinking and grafting to prepare covalently-attached cyclodextrins, and applications in the food and pharmaceutical sectors, from an historical point of view. In food science, applications include debittering of juices, retention of aromas and release of preservatives from packaging. In biomedical science, cyclodextrin polymers are applied classically to drug release, and more recently to gene delivery and regenerative medicine. The remarkable points are: 1) epichlorohydrin and diisocyanates have been extensively used as crosslinkers since the 1960s, but during the last two decades more complex cyclodextrin polymeric structures have been designed. 2) The evolution of cyclodextrin polymers matches that of macromolecular materials with regard to complexity, functionality and capabilities. 3) The use of cyclodextrin polymers as sorbents in the food sector came first, but smart packaging is now an active challenge. Cyclodextrins have also been recently used to design treatments against the coronavirus disease 2019 (COVID-19).
\end{abstract}

Keywords Cyclodextrin polymers $\cdot$ Crosslinking $\cdot$ Drug delivery $\cdot$ Regenerative medicine $\cdot$ Food packaging

\section{Abbreviations}

DNA Deoxyribonucleic acid

NMR Nuclear magnetic resonance

\section{Introduction}

In addition to their remarkable capability to establish supramolecular host-guest interactions because of their toroidal shape and non-polar inside (Morin-Crini et al. 2021), cyclodextrins can also be covalently attached in different ways to

José Ramón Isasi

jrisasi@unav.es

Max Petitjean

mpetitjean@alumni.unav.es

Iñigo X. García-Zubiri

inigo.garcia@magnesitasnavarras.es

1 Departamento de Química, Facultad de Ciencias, Universidad de Navarra, c/ Irunlarrea 1, 31008 Pamplona, Spain

2 MAGNESITAS NAVARRAS, S.A, Av. Roncesvalles, 31630 Zubiri, Navarra, Spain

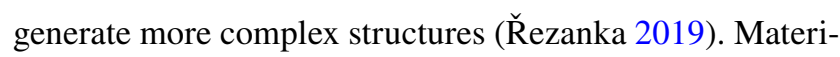
als containing more than two covalently linked cyclodextrin units are known as cyclodextrin polymers, and their uses in the field of remediation technologies have been widely explored (Landy et al. 2012). In the case of drug delivery, the most frequently investigated subject among the biomedical applications, the complexation capabilities of cyclodextrins and the controlled release rate of the guest drugs can be modulated with the aid of the additional functionality of a polymeric macrostructure. In other cases, the covalent attachment of cyclodextrin moieties to a pre-existing structure is intended to immobilize them, as in the case of medical devices or packaging applications.

This review covers, from a historical point of view, the applications both in food chemistry and pharmaceutics and biomedicine of cyclodextrin polymers (see Fig. 1). In contrast to the enormous amount of studies on the uses of the parent cyclodextrins in these two sectors, cyclodextrin polymer references are not as abundant and most of the examples found in the literature correspond to the last 10-15 years.

We can define cyclodextrin polymers as those materials or molecules containing more than two covalently linked cyclodextrin units. Thus, we will not cover in the following 


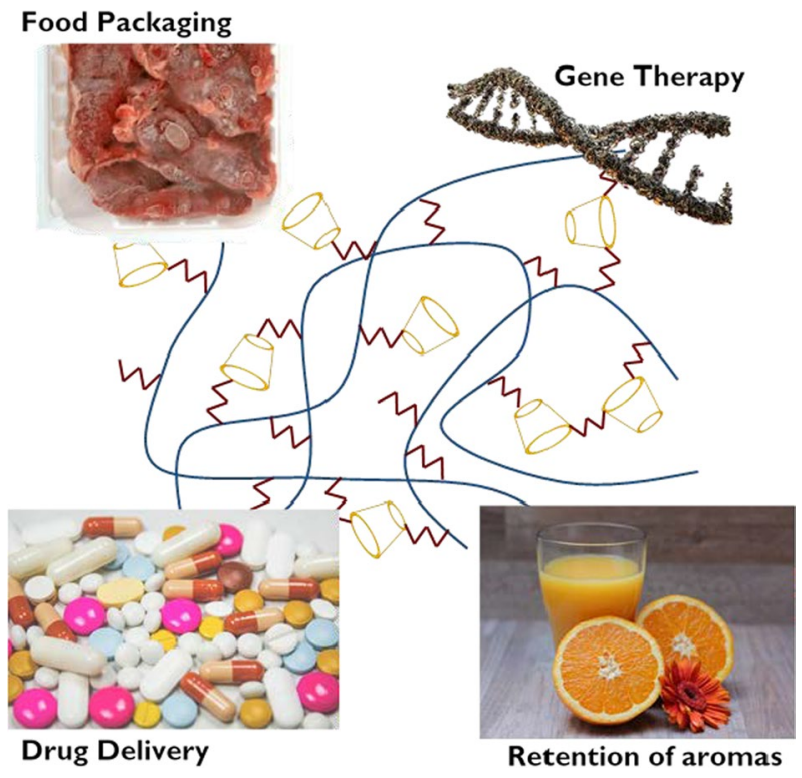

Fig. 1 Uses of cyclodextrin polymers in the food and pharmaceutical sectors

sections of this review either the functionalization of nonpolymeric supports, known as cyclodextrin nanocomposites, or the amphiphilic cyclodextrins and star polymers with a cyclodextrin core, or the cyclodextrins threaded onto polymer chains, known as polyrotaxanes.

The first references dealing with the potential use of cyclodextrin-containing covalent structures as macromolecular carriers, date back to the 1980s. Since then, they have been incorporated into many constructions, such as hydrogels, nanosponges, dendrimers, interpenetrating networks, molecular imprinted polymers or electrospinned fibres. In addition, some of these systems have proved to be responsive to stimuli, leading to the design of smart multifunctional biomaterials that can be triggered by different factors. This article is an abridged and updated version of the chapter published by Petitjean et al. (2020) in the series Environmental Chemistry for a Sustainable World.

\section{Cyclodextrin polymers}

\section{Historical perspective of cyclodextrin polymers}

The pioneering work of Solms and Egli in 1965 can be considered as the first landmark in the field of cyclodextrin polymers (Solms and Egli 1965). Also in those early years, Wiedenhof et al. (1969) improved the properties of the irregular crosslinked cyclodextrin particles and produced bead microparticles that, for instance, were suitable to be used in chromatographic columns.

Polyurethane cyclodextrin networks were prepared using diisocyanates by Buckler et al. (1969). Acid dihalides and many other potentially useful space arms were also considered in the same patent and various possible applications of those "anchored" cyclodextrins were explored.

A few years after that, in the mid-1970s, the first cyclodextrin monomers were produced and polymerized by Furue et al. (1975). This acrylic polymer exhibited a greater catalytic effect in the hydrolysis of $p$-nitrophenyl esters due to the "cooperative effect" between two neighbouring cyclodextrin moieties on a polymeric chain (Harada et al. 1977) (Fig. 2).

The next type of cyclodextrin polymers in our classification corresponds to the attachment of cyclodextrin moieties to previously existing macromolecular materials. In this case, Szejtli, Fenyvesi et al. attached cyclodextrin units to polyvinyl alcohol using epichlorohydrin and epoxy ethers in the late 1970s (Szetjli et al. 1979). Hirayama et al. (1984) used epichlorohydrin to prepare a $\beta$-cyclodextrin/starch composite gel. In the 1990s, Pöpping and Deratani (1992) reported the production of
Fig. 2 Cyclodextrin-containing macromolecular systems: a crosslinked cyclodextrin polymers (more than three units); b linear polymers, either grafted-cyclodextrin polymers or monomeric cyclodextrin (co) polymers; $\mathbf{c}$ amphiphilic and star-like unimeric cyclodextrins; d (pseudo)polyrotaxanes; $\mathbf{e}$ nanocomposites and immobilized cyclodextrins. Only the first two types of structures are covered in this review

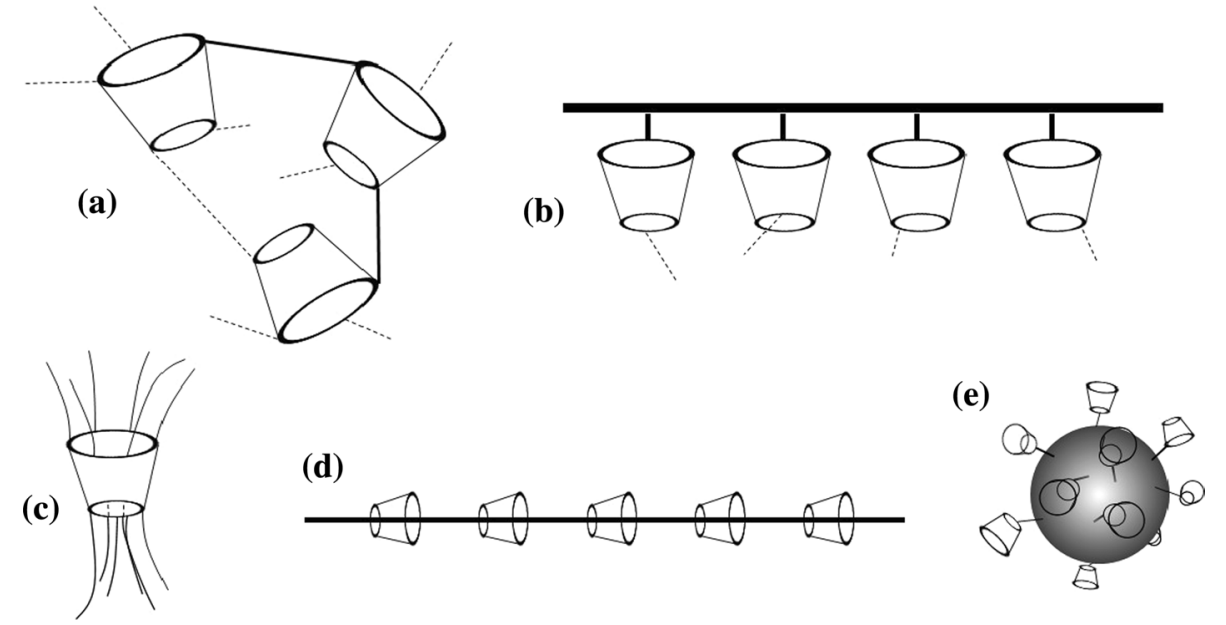


monochlorinated cyclodextrins and, later on, other derivatives containing heterocycles were synthesized (Reuscher et al. 1998). Earlier, in 1981, Tanaka et al. had immobilized derivatives of $\alpha$ - and $\beta$-cyclodextrin on polyurethane and also onto a polyacrylamide support after activating it with succinyl hydrazide (Tanaka et al. 1981, 1982) with the aim of obtaining stationary phases for the separation of benzene derivatives. About twenty years ago, Crini et al. used cyclodextrin tosyl derivatives to produce macroporous polyamines (1998a) or to modify polyethyleneimines in order to coat silica beads (Crini et al. 1995). Cyclodextrin side chain polyesters were also obtained in those years (Weickenmeier and Wenz 1996). Wenz et al. also reported the synthesis of thickeners based on the specific interaction between cyclodextrin polymers and guest polymers (Weickenmeier and Wenz 1996).

A comprehensive collection of the first polymers can be found in the review of cyclodextrin-containing adsorbents by Crini and Morcellet (2002). In the last two decades, more complex cyclodextrin polymer structures have been produced, namely interpenetrated networks, molecular imprinted polymers, dendrimers, nanogels, polymer assemblies, and nanocomposites. The especial cases of the feasible uses of these materials in these two sectors will be the goal of the last section of this review.

\section{Covalent and supramolecular architectures}

\section{Cyclodextrins crosslinked in covalent networks}

Cyclodextrin crosslinked with epichlorohydrin polymers, the most abundant in the literature, were also the first type known, synthesized by Solms and Egli (1965). The reaction of saccharides such as glucose with epichlorohydrin is well known (Dumitriu 1996), and the primary product of the reaction of $\beta$-cyclodextrin with epichlorohydrin in alkaline media is a heterogeneous mixture of several ethers, of low molecular weight and viscosity, soluble in water. In this reaction, the self-polymerisation of epichlorohydrin, which is favoured at high temperatures, can also occur (Renard et al. 1997).

The bulk synthesis procedure of Solms and Egli (1965) produced irregular polymer particles. A few years after that, Wiedenhof et al. (1969) proposed a two-phase emulsion polymerisation with controlled stirring, in which the cyclodextrin dissolved in water is dispersed in a non-polar organic solvent containing a non-ionic surfactant and the crosslinker in order to produce uniform microspheres, or beads, with better physicochemical properties. As potential drug delivery devices, cyclodextrin-epichlorohydrin hydrogels made with a controlled geometry are useful to obtain kinetic parameters (Machín et al. 2012).
Among the most frequently used non-epoxide crosslinkers are diisocyanates, first introduced by Buckler et al. (1969), as mentioned above. Dihalogenated acid dihalides or dihalogenated dicarboxylic acids of different sizes have also been used as space arms (Buckler et al. 1969; Zemel and Koch 1990), besides other agents such as dihalogenated alkenes or, later on, maleic anhydride (Girek et al. 2000). Shono et al. prepared insoluble porous polymers with a high cyclodextrin content, polymerising $\alpha$ - and $\beta$-cyclodextrin with diisocyanates as crosslinking agents in pyridine or dimethylformamide, and studied their capability to absorb aromatic derivatives (Mizobuchi et al. 1980; Tanaka et al. 1981). Certain properties and applications have been studied thereof: stationary phases in chromatography (Lee et al. 2002); artificial cholesterol receptors (Asanuma et al. 1998); solid phase for the extraction of carcinogenic aromatic compounds (Bhaskar et al. 2004). Ma's group, which also used these two diisocyanates, postulated the presence of interconnected nanoporosity in these polymers ( $\mathrm{Li}$ and Ma 1999; $\mathrm{Ma}$ and Li 1999). The use of difunctional crosslinkers with longer spacers can lead to macromolecular networks with increased porosity, more flexible and less compact. In these networks, smaller molecules can increase their diffusion rates and bulkier substances may also become entrapped (Mocanu et al. 2001). The use of non-toxic crosslinkers like the polycarboxylic acids is also feasible. Martel's group described the synthesis of soluble and insoluble polymers (Martel et al. 2005) and the production of cotton-bound cyclodextrin using these crosslinkers (Martel et al. 2002).

The analysis of cyclodextrin polymers crosslinked with epichlorohydrin is complicated when it comes to infrared or Raman spectroscopic techniques (Crini et al. 2000) because, as mentioned above, both the crosslinked cyclodextrin units and the self-polymerised epichlorohydrin possess hydroxyalkyl and ether groups. Nevertheless, the interpretation of the infrared spectra of starch crosslinked with epichlorohydrin was resolved at the time (Dumoulin et al. 1998; Delval et al. 2004).

While the spectroscopic characterization of cyclodextrin-epichlorohydrin polymers is not easy, that of cyclodextrin polymers crosslinked with diisocyanates seemed to be simpler. Qualitative characterizations by infrared spectroscopy (Li and Ma 1999; Bhaskar et al. 2004) or Raman (Lee et al. 2002) were attempted, and the successful quantitative analysis was achieved thanks to the intense carbonyl band of the crosslinker (García-Zubiri 2005). Thermal and thermogravimetric analysis were also used in most of those studies, as well as NMR spectroscopy (Asanuma et al. 1998; Lee et al. 2002). For polymers with other crosslinkers, such as maleic anhydride, there were also some NMR results of interest (Girek et al. 2000).

As for the cyclodextrin content of the polymer, the most common procedures used already in the 1990s were the 
colorimetric methods using chlorotetrazolium blue (Crini et al. 1995; 1998b; Janus et al. 1999) or iodometry (Renard et al. 1997) and phenolphthalein (Mäkelä et al. 1987). For soluble cyclodextrin polymers, proton nuclear magnetic resonance spectroscopy could be used (Renard et al. 1997), and for the insoluble resins ${ }^{1} \mathrm{H}$ or ${ }^{13} \mathrm{C}$ solid-state NMR were employed (Crini et al. 1998b; 2000).

Another technique used to determine the cyclodextrin content in the polymers is CHN elemental analysis (Lee et al. 2002). Nevertheless, it must be used with great care in the case of cyclodextrin-epichlorohydrin polymers due to the similar elemental composition of both constituents (Romo et al. 2006). Important advances in this area have been achieved along the years but the precise characterization of cyclodextrin polymers continues being a challenge as occurs in any other macromolecular materials.

\section{Other novel cyclodextrin polymers}

The reticulated cyclodextrins, also known as nanosponges, have evolved into more complex structures in the last 10-20 years (Caldera et al. 2017). Thus, molecular imprinted polymers using cyclodextrin moieties were already produced in the late 1990s (Piletsky et al. 1998). Stimuli responsive polymers based on cyclodextrins were prepared in 1995 using the ubiquitous $\mathrm{N}$-isopropylacrylamide monomer (Nozaki et al. 1995). Interpenetrated networks containing cyclodextrins also appeared at that time (Sreenivasan 1997). Fenyvesi et al. encapsulated several cationic disinfectant agents, in chemically modified (carboxymethylated) nanosponges, based on cyclodextrin linked to polyvinyl alcohol, to be used in the prolonged treatment of wounds (1996).

Nanogels combine the advantages of hydrogels and nanoparticles into a single carrier (Moya-Ortega et al. 2012). Liu et al. prepared cyclodextrin microgels, including one interpenetrated network, by inverse-emulsion polymerisation (2004). About ten years ago, nanoparticles were synthesized by a one-step condensation polymerisation of $\beta$-cyclodextrin, choline chloride and epichlorohydrin by Gil et al. (2009). The top-down approach can break bigger networks into the nanoscale size by using ultrasounds (Swaminathan et al. 2010). The water-in-oil emulsion method has been thoroughly employed in the last decade, but their direct synthesis by polymerisation of cyclodextrin monomers is more rare (Moya-Ortega et al. 2012).

Another interesting method of producing nanogels was designed by Gref et al. and consist on supramolecular nanoassemblies between a cyclodextrin-epichlorohydrin polymer and an alkyl-grafted dextran (Gref et al. 2006). Other potential uses of cyclodextrins as 'smart' components of polymer nanoparticles were reviewed by Gref and Duchêne (2012). A variety of cyclodextrin-based architectures, e.g. linear, dendrimers, stars, polyrotaxanes, were used in the preparation of polyplexes for gene delivery (Mellet et al. 2011). In 1997, $\beta$-cyclodextrin was attached to dendrimer polyethyleneimines (Suh et al. 1997). Two years later, linear cationic alternate copolymers capable of binding DNA with transfection efficiency were prepared by Davis' group (Gonzalez et al. 1999). Later on, Choi et al. prepared polyplexes grafting cyclodextrin to poly-L-lysine instead of using poly(ethyleneimine) (2005).

Electrospun nanofibres have been used as drug delivery materials due to their high specific area and, obviously, various formulations including cyclodextrins have been tested in the last 5 years (Costoya et al. 2017). Cyclodextrin polymers have been also explored as components of electrospun nanofibres recently (Oliveira et al. 2015). As shown in this short account of the major findings in this field, the evolution of cyclodextrin polymers goes in parallel with the progress in the production of novel macromolecular materials with more complex structures and morphologies, controlled or 'smart' behaviours, and specific applications.

\section{Applications in the food and pharmaceutical areas}

\section{Cyclodextrin polymers in food science}

In the food industry, cyclodextrins have been applied as sorption/release agents and for packaging purposes (Sarkar et al. 2017). They can be used as single cyclodextrins incorporated into fibres (Celebioglu et al. 2018) or films (Plackett et al. 2006). Crosslinked cyclodextrins were firstly proposed for food related applications as early as the 60 s with the patent of Bucker et al. (1969) as agents for concentration of flavours or aromas in the food industry.

Cyclodextrin-epichlorohydrin polymers were developed to reduce the bitterness of fruit juices (Shaw et al. 1984), and a selectivity study between bitter molecules and caffeine was tested (Shaw and Buslig 1986), using $\gamma$-cyclodextrin polymer as well. It was proved that cyclodextrin polymers do not complex with the latter and studied the importance of the crosslinking agent.

For the same application, $\beta$ - or $\gamma$-cyclodextrin was linked to chitosan through succinyl or maleyl bridges to improve the sorption of bitter compounds (Binello et al. 2004). Thanks to a pilot-plant fluidised-bed procedure, Wagner successes a regeneration of $\beta$-cyclodextrin polymer over twenty times without apparent loss of capacity (1988). The debittering of other juices has also been reported later (Szejtli and Szente 2005).

In the last decade, another area of application searched in food science and cosmetics is the retention of fragrance or aroma molecules. Encapsulation of linalool and camphor, composing Lavandula angustifolia essential oil, using 
crosslinked cyclodextrin-epichlorohydrin polymers was compared to those of the parent and derivative cyclodextrins (Ciobanu et al. 2012). To absorb unwanted molecules present in wine, beads produced using epichlorohydrin (FliszárNyúl et al. 2020) or hexamethylene diisocyanate can be used (Dang et al. 2020).

In 2009, cyclodextrin polymers were used in solid phase extractions to determine additives in food ( $\mathrm{Li}$ et al. 2009). In parallel, molecular imprinted cyclodextrin polymers were prepared using monomeric cyclodextrin/maleic acid with Congo Red as template and N,N'-methylenebisacrylamide as crosslinker (Liu et al. 2015). Also, a cyclodextrin polymer with a higher specific area has been prepared (Li et al. 2018), grafted onto metallic graphene ( $\mathrm{Li}$ et al. 2016a), added to ionic liquids (Feng et al. 2015), or imprinted on carbon nanotubes (Liang et al. 2019), in order to remove and/or determine the amount of organic molecules present in food.

Single cyclodextrins are also common for food packaging; they began to be exploited for that purpose at the end of the past century (Szente and Fenyvesi 2018). The first reported use of a cyclodextrin polymer in packaging was to remove an undesirable product in food such as cholesterol (López-De-Dicastillo et al. 2011).

On the other hand, active films are designed to liberate chemicals encapsulated in them using UV stimuli (Tan et al. 2016). To achieve an antibacterial potential, it is also feasible to integrate $\mathrm{ZnO}$ nanoparticles into polymer films (AndradeDel Olmo et al. 2019) or to crosslink a sorbate/cyclodextrin complex, such that with sodium benzoate (Yang et al. 2019). Starting with the applications to extract unwanted molecules from food products several decades ago, the modern uses of cyclodextrin polymers focus also on smart packaging.

\section{Cyclodextrin polymers in drug delivery}

The first reviewing of the potential applications of cyclodextrin polymers in the pharmaceutical industry was written by Fenyvesi (1988), and it was mainly based on cyclodextrin crosslinked with epichlorohydrin. A pioneering bioavailability study using a soluble cyclodextrin polymer was reported in the mid-1980s (Uekama et al. 1985). The absorptionpromoting effect of the soluble cyclodextrin polymer on the sublingual route was also demonstrated in the case of steroids (Pitha et al. 1986). Karadake et al. (1982) showed that the drug release was retarded and the stability against oxidation and degradation was greatly increased when penicillin complexed with soluble cyclodextrin polymer was microencapsulated.

On the other hand, some applications of the insoluble crosslinked cyclodextrin polymers were also investigated. For instance, its effect on wound healing was tried on tissues of rats (Felméray et al. 1996). In addition, the cyclodextrin-epichlorohydrin sorption capabilities were tested for the removal of phenylalanine from a protein hydrolysate in order to make it digestible for children suffering from phenylketonuria (Specht et al. 1981). Also at that time, the effectiveness of a cyclodextrin polymer as a tablet disintegrant was studied in direct compression systems (Fenyvesi et al. 1984).

Those first attempts to show their capabilities in the sorption and release of aromatic model molecules pointed to the use of cyclodextrin polymers as controlled release agents (Friedman et al. 1989). Specifically, the release of cetylpyridinium chloride, an antimicrobial agent, and iodine, using cyclodextrin polymers, were patented in the late 1980s (Friedman 1988; Szejtli et al. 1988). An earlier example of a cyclodextrin polymer as a macromolecular carrier in the field of antitumor chemotherapy was published also in the mid-1980s (Kaji et al. 1985).

The following decade showed only a few other distinct examples in drug delivery. Thus, drugs complexed in cyclodextrin polymers were entrapped into liposomes (McCormack and Gregoriadis 1994). On the other hand, the need to prepare degradable materials for medical applications, including drug delivery, associating networks using cyclodextrin-epichlorohydrin polymers and degradable copolyesters containing adamantyl groups were tested and were shown to be $\mathrm{pH}$ sensitive (Cammas et al. 1999).

Cyclodextrin-based nanosponges have been designed in the last years to increase the dissolution rate, the solubility and stability of drugs, or to prolong the release time, and also applied in semisolid formulations for skin delivery (Ansari et al. 2011; Shende et al. 2013; Conte et al. 2014). Recently, experimental design has been used to formulate tablets using polymeric nanosponges for a combination therapy of three anti-inflammatory drugs (Moin et al. 2020).

As mentioned above, cyclodextrin moieties can be incorporated to pre-existing polymeric materials via grafting reactions. In most of the drug delivery applications, cyclodextrins are attached to polysaccharides (Luzardo-Alvarez et al. 2014), such as chitosan, for which the adsorption and release of ketoprofen, a model drug, was evaluated some time ago (Prabaharan and Mano 2005). Although cyclodextrin adds new drug inclusional properties to the polycationic polymer, a decrease in mucoadhesion of cyclodextrin-chitosan was observed (Venter et al. 2006). More recently, cellulosic substrates were grafted by a cyclodextrin polymer to sustain the release of antibacterial agents (Cusola et al. 2013). Other materials such as poly(hydroxyethylmethacrylate) have also been grafted with $\beta$-cyclodextrin for its application in soft contact lenses conservation liquids and to sustain drug delivery in the lacrimal fluid (dos Santos et al. 2009). The use of some cyclodextrin polymers for therapeutics delivery was patented in 2013 (Cheng et al. 2013). 
In the turn of the century, a new class of polymers for the delivery of macromolecular therapeutics arose (Gonzalez et al. 1999). Thus, low molecular weight polyethylenimine crosslinked by cyclodextrins demonstrated its lower cytotoxicity and higher transfection efficiency for the delivery of plasmid DNA compared with those of polyethylenimine (Huang et al. 2006). Another significant achievement has been, for instance, the use of a specific functional group such as folic acid grafted to polyethyleneimine-cyclodextrin carriers, to target the tumour cells (Yao et al. 2009). Intranasal mRNA vaccination with the aid of a cationic cyclodextrinpolyethyleneimine conjugate, capable of overcoming the nasal epithelial barrier, has also been recently proposed $(\mathrm{Li}$ et al. 2016b).

Drug release behaviour can be modulated with the aid of stimuli responsive polymers and the design of interpenetrated networks (interpenetrated network) permits to combine the temperature responsiveness of poly( $\mathrm{N}$-isopropylamide) gels with the inclusional capabilities of cyclodextrin networks (Zhang et al. 2005). Another semi-interpenetrated network was prepared by the radical polymerisation and crosslinking of $\mathrm{N}$-isopropylacrylamide in the presence of $\beta$-cyclodextrin-grafted polyethylenimine (Zhang et al. 2008). Interpenetrated networks can also be used to develop new selective and synergistic sorption capacities for specific purposes such as a combined drug release (Fujiyoshi et al. 2019).

A remarkable $\mathrm{pH}$-responsive behaviour can be achieved using acrylic acid containing polymers (Siemoneit et al. 2006). Other examples have been reported in the recent literature: highly $\mathrm{pH}$-dependent swelling in graft cyclodextrin/ acrylic acid copolymers for the delivery of ketoprofen (Wang et al. 2009), or mucoadhesive hydrogels by the crosslinking of poly(acrylic acid) with cyclodextrins for the controlled release of diflunisal and fluconazole (Kutyła et al. 2013). A biocompatible system based on guar gum, poly(acrylic acid) and $\beta$-cyclodextrin using a non-toxic crosslinker, tetraethyl orthosilicate, for intestinal delivery of dexamethasone, has also been reported (Das and Subuddhi 2015). A combination of cocktail chemotherapy, photothermal therapy and inhibition of angiogenesis was investigated using an injectable nanocarrier developed by functionalization of carbon nanotubes with a $\mathrm{pH}$ a thermoresponsive cyclodextrin polymer (Das et al. 2020).

In the last decade, triple-response $(\mathrm{pH}$, temperature, and glucose) semi-interpenetrated hydrogels were prepared by polymerisation in the presence of the magnetite $\left(\mathrm{Fe}_{3} \mathrm{O}_{4}\right)$ nanoparticles, a cyclodextrin/epichlorohydrin polymer and a crosslinker (Huang et al. 2012). More recently, a carboxymethyl- $\beta$-cyclodextrin polymer was grafted on the surface of chitosan-coated magnetite nanoparticles by an emulsion chemical crosslinking method (Ding et al. 2015).

Finally, cyclodextrin polymers have also recently found applications in the field of regenerative medicine (AlvarezLorenzo et al. 2017). Vascular polyester and polyamide prostheses can be coated with grafted cyclodextrins that can be loaded with an antibiotic in order to reduce the risk of post-operative infections (Blanchemain et al. 2005). Polyvinylidene difluoride membranes can also be grafted with cyclodextrins to improve the capture and subsequent release of antiseptic agents (Tabary et al. 2007). Polyamide inguinal meshes (El Ghoul et al. 2008) or polypropylene abdominal wall implants for the prolonged delivery of ciprofloxacin (Laurent et al. 2011) have been prepared using citric acid as a crosslinker. Hydroxyapatite used in bone implants can also be functionalized with a cyclodextrin polymer for loading antibiotics (Hoang Thi et al. 2010; Taha et al. 2014). Recently, injectable hydrogels of polyelectrolyte complexes between chitosan and cyclodextrin polymers have been rheologically tested (Palomino-Durand et al. 2019).

As in the case of 'monomeric' both natural and derivative cyclodextrins, an increasing number of publications can be found in the most recent literature concerning cyclodextrin polymers, e.g. about 80 papers and reviews in 2020 . As Table 1 shows, many reviews have been published in the last six years, and the interested reader is referred to them to acquire a better idea of the goals this field of research is heading and the paths, or approaches, taken. In addition, some other recent reviews also include a section on cyclodextrin-based systems (Larrañeta et al. 2018; Levack et al. 2018; Solanki et al. 2018; Gim et al. 2019). Cyclodextrins have also been recently used to design treatments against the coronavirus disease 2019 (COVID-19) (Carrouel et al. 2020; Ergoren et al. 2020; Sofiane et al. 2020; Szente et al. 2021).

\section{Conclusion}

Immobilized cyclodextrins were first used in the food industry to improve taste, extract some nutrients or flavours, or, more recently, as constituents of the smart packaging of comestible products. The capabilities of the parent and modified cyclodextrins as carriers of substances of low solubility, such as most drugs, were soon exploited for pharmaceutical applications as well. Although the research involving these polymers in the food sector is comparatively scarce, the potential uses in the pharmaceutical and medical sector have been thoroughly investigated, especially in the last decade. A 
Table 1 Recent reviews (2015-2021) on the applications of cyclodextrins and cyclodextrin polymers in pharmacy and biomedicine

\begin{tabular}{|c|c|}
\hline Authors and year & Review title \\
\hline Simões et al. (2015) & Supramolecular cyclodextrin-based drug nanocarriers \\
\hline Osmani et al. (2015) & Cyclodextrin-based nanosponges: Impending carters in drug delivery and nanotherapeutics \\
\hline Wei and Yu (2015) & Cyclodextrin-functionalized polymers as drug carriers for cancer therapy \\
\hline Gidwani and Vyas (2015) & $\begin{array}{l}\text { A comprehensive review on cyclodextrin-based carriers for delivery of chemotherapeutic cytotoxic anti- } \\
\text { cancer drugs }\end{array}$ \\
\hline Gonzalez-Gaitano et al. (2016) & $\begin{array}{l}\text { Drug carrier systems based on cyclodextrin supramolecular assemblies and polymers: present and per- } \\
\text { spectives }\end{array}$ \\
\hline Mejia-Ariza et al. (2017) & Cyclodextrin-based supramolecular nanoparticles for biomedical applications \\
\hline Peng et al. (2017) & $\begin{array}{l}\text { Polymeric nanocarriers based on cyclodextrins for drug delivery: host-guest interaction as stimuli respon- } \\
\text { sive linker }\end{array}$ \\
\hline Adeoye and Cabral-Marques (2017) & Cyclodextrin nanosystems in oral drug delivery: A mini review \\
\hline Alvarez-Lorenzo et al. (2017) & Cyclodextrins as versatile building blocks for regenerative medicine \\
\hline Fenyvesi et al. (2019) & Applications of steroid drugs entrapped in cyclodextrins \\
\hline Topuz and Uyar (2019) & Electrospinning of cyclodextrin functional nanofibres for drug delivery applications \\
\hline Yao et al. (2019) & Cyclodextrin-based polymer materials: From controlled synthesis to applications \\
\hline Zhang et al. (2019) & Cyclodextrin-based delivery systems for cancer treatment \\
\hline Ciesielska et al. (2020) & Biomedical application of cyclodextrin polymers crosslinked via dianhydrides of carboxylic acids \\
\hline Haley et al. (2020) & Cyclodextrins in drug delivery: applications in gene and combination therapy \\
\hline Qie et al. (2020) & Advances in cyclodextrin polymers and their applications in biomedicine \\
\hline Seidi et al. (2020) & Polycyclodextrins: synthesis, functionalization, and applications \\
\hline Tian et al. (2020a) & Cyclodextrin-based delivery systems for chemotherapeutic anticancer drugs: a review \\
\hline Tian et al. (2020b) & Cyclodextrin as a magic switch in covalent and non-covalent anticancer drug release systems \\
\hline Wankar et al. (2020) & $\begin{array}{l}\text { Recent advances in host-guest self-assembled cyclodextrin carriers: implications for responsive drug } \\
\text { delivery and biomedical engineering }\end{array}$ \\
\hline Sofiane et al. (2020) & $\begin{array}{l}\text { The use of cyclodextrin or its complexes as a potential treatment against the } 2019 \text { novel coronavirus: a } \\
\text { mini-review }\end{array}$ \\
\hline
\end{tabular}

vast amount of papers are currently being published in order to explore the applicability of these interesting materials.

Acknowledgements The authors wish to thank University of Navarra (PIUNA 2018-15) for the financial support and MP gratefully acknowledges Asociación de Amigos (Universidad de Navarra) for his grant.

\section{References}

Adeoye O, Cabral-Marques H (2017) Cyclodextrin nanosystems in oral drug delivery: a mini review. Int J Pharm 531:521-531. https:// doi.org/10.1016/j.ijpharm.2017.04.050

Alvarez-Lorenzo C, García-González CA, Concheiro A (2017) Cyclodextrins as versatile building blocks for regenerative medicine. J Control Release 268:269-281. https://doi.org/10.1016/j.jconr el.2017.10.038

Andrade-Del Olmo J, Pérez-Álvarez L, Hernáez E, Ruiz-Rubio L, Vilas-Vilela JL (2019) Antibacterial multilayer of chitosan and (2-carboxyethyl)- $\beta$-cyclodextrin onto polylactic acid (poly-L-lactic acid). Food Hydrocoll 88:228-323. https://doi.org/10.1016/j. foodhyd.2018.10.014

Ansari KA, Vavia PR, Trotta F, Cavalli R (2011) Cyclodextrin-based nanosponges for delivery of resveratrol: in vitro characterisation, stability, cytotoxicity and permeation study. AAPS PharmSciTech 12:279-286. https://doi.org/10.1208/s12249-011-9584-3
Asanuma H, Kakazu M, Shibata M, Hishiya T, Komiyama M (1998) Synthesis of molecularly imprinted polymer of $\beta$-cyclodextrin for the efficient recognition of cholesterol. Supramol Sci 5:417-421. https://doi.org/10.1016/S0968-5677(98)00042-X

Bhaskar M, Aruna P, Jeevan RJG, Radhakrishnan G (2004) $\beta$-Cyclodextrin-polyurethane polymer as solid phase extraction material for the analysis of carcinogenic aromatic amines. Anal Chim Acta 509:39-45. https://doi.org/10.1016/j.aca.2003.12.015

Binello A, Cravotto G, Nano GM, Spagliardi P (2004) Synthesis of chitosan-cyclodextrin adducts and evaluation of their bittermasking properties. Flavour Fragr J 19:394-400. https://doi. org/10.1002/ffj.1434

Blanchemain N, Haulon S, Martel B, Traisnel M, Morcellet M, Hildebrand HF (2005) Vascular PET prostheses surface modification with cyclodextrin coating: development of a new drug delivery system. Eur J Vasc Endovasc Surg 29:628-632. https://doi.org/ 10.1016/j.ejvs.2005.02.020

Buckler SA, Martel RF, Moshy RJ (1969) Schardinger dextrins. United States Pat. Off. 3472835

Caldera F, Tannous M, Cavalli R, Zanetti M, Trotta F (2017) Evolution of cyclodextrin nanosponges. Int J Pharm 531:470-479. https:// doi.org/10.1016/j.ijpharm.2017.06.072

Cammas S, Béar M-M, Moine L, Escalup R, Ponchel G, Kataoka K, Guérin P (1999) Polymers of malic acid and 3-alkylmalic acid as synthetic PHAs in the design of biocompatible hydrolyzable devices. Int J Biol Macromol 25:273-282. https://doi.org/10. 1016/S0141-8130(99)00042-2

Carrouel F, Pia Conte M, Fisher J, Souza Gonçalves L, Dussart C, Carlos Llodra J, Bourgeois D (2020) COVID-19: a recommendation 
to examine the effect of mouthrinses with $\beta$-cyclodextrin combined with citrox in preventing infection and progression. J Clin Med 9(4):1126

Celebioglu A, Yildiz ZI, Uyar T (2018) Fabrication of electrospun eugenol/cyclodextrin inclusion complex nanofibrous webs for enhanced antioxidant property, water solubility, and high temperature stability. J Agric Food Chem 66:457-466. https://doi. org/10.1021/acs.jafc.7b04312

Cheng J, Davis ME, Khin KT (2013) Cyclodextrin-based polymers for therapeutic delivery. United States Pat. Off. 8389499

Choi HS, Yamashita A, Ooya T, Yui N, Akita H, Kogure K, Ito R, Harashima H (2005) Sunflower-shaped cyclodextrin-conjugated poly( $\varepsilon$-lysine) polyplex as a controlled intracellular trafficking device. ChemBioChem 6:1986-1990. https://doi.org/10.1002/ cbic. 200500242

Ciesielska A, Ciesielski W, Girek B, Girek T, Koziel K, Kulawik D, Lagiewka J (2020) Biomedical application of cyclodextrin polymers cross-linked via dianhydrides of carboxylic acids. Appl Sci 10:8463. https://doi.org/10.3390/app10238463

Ciobanu A, Mallard I, Landy D, Brabie G, Nistor D, Fourmentin S (2012) Inclusion interactions of cyclodextrins and crosslinked cyclodextrin polymers with linalool and camphor in Lavandula angustifolia essential oil. Carbohydr Polym 87:1963-1970. https://doi.org/10.1016/j.carbpol.2011.10.005

Conte C, Caldera F, Catanzano O, D'Angelo I, Ungaro F, Miro A, Pellosi DS, Trotta F, Quaglia F (2014) $\beta$-cyclodextrin nanosponges as multifunctional ingredient in water-containing semisolid formulations for skin delivery. J Pharm Sci 103:3941-3949. https:// doi.org/10.1002/jps. 24203

Costoya A, Concheiro A, Alvarez-Lorenzo C (2017) Electrospun fibers of cyclodextrins and poly(cyclodextrins). Molecules. https://doi. org/10.3390/molecules 22020230

Crini G, Morcellet M (2002) Synthesis and applications of adsorbents containing cyclodextrins. J Sep Sci 25:789-813. https://doi.org/ 10.1002/1615-9314(20020901)25:13\%3c789::AID-JSSC789\% 3e3.0.CO;2-J

Crini G, Lekchiri Y, Morcellet M (1995) Separation of structural isomers using cyclodextrin-polymers coated on silica beads. Chromatographia 40:296-302. https://doi.org/10.1007/BF02290360

Crini G, Janus L, Morcellet M, Torri G, Naggi A, Bertini S, Vecchi C (1998a) Macroporous polyamines containing cyclodextrin: synthesis, characterization, and sorption properties. J Appl Polym Sci 69:1419-1427. https://doi.org/10.1002/(SICI)10974628(19980815)69:7\%3c1419::AID-APP17\%3e3.0.CO;2-O

Crini G, Cosentino C, Bertini S, Naggi A, Torri G, Vecchi C, Janus L, Morcellet M (1998b) Solid state NMR spectroscopy study of molecular motion in cyclomaltoheptaose ( $\beta$-cyclodextrin) crosslinked with epichlorohydrin. Carbohydr Res 308:37-45. https://doi.org/10.1016/S0008-6215(98)00077-9

Crini G, Bourdonneau M, Martel B, Piotto M, Morcellet M, Richert T, Vebrel J, Torri G, Morin N (2000) Solid-state NMR characterization of cyclomaltoheptaose ( $\beta$-cyclodextrin) polymers using high-resolution magic angle spinning with gradients. J Appl Polym Sci 75:1288-1295. https://doi.org/10.1002/(SICI)10974628(20000307)75:10\%3c1288::AID-APP10\%3e3.0.CO;2-J

Cusola O, Tabary N, Belgacem MN, Bras J (2013) Cyclodextrin functionalization of several cellulosic substrates for prolonged release of antibacterial agents. J Appl Polym Sci 129:604-613. https:// doi.org/10.1002/app.38748

Dang C, Jiranek V, Taylor DK, Wilkinson KL (2020) Removal of volatile phenols from wine using crosslinked cyclodextrin polymers. Molecules 25(4):1-14. https://doi.org/10.3390/molecules250409 10

Das S, Subuddhi U (2015) pH-Responsive guar gum hydrogels for controlled delivery of dexamethasone to the intestine. Int J Biol
Macromol 79:856-863. https://doi.org/10.1016/j.ijbiomac.2015. 06.008

Das M, Nariya P, Joshi A, Vohra A, Devkar R, Seshadri S, Thakore S (2020) Carbon nanotube embedded cyclodextrin polymer derived injectable nanocarrier: a multiple faceted platform for stimulation of multi-drug resistance reversal. Carbohydr Polym 247:116751. https://doi.org/10.1016/j.carbpol.2020.116751

Delval F, Crini G, Bertini S, Morin-Crini N, Badot PM, Vebrel J, Torri G (2004) Characterization of crosslinked starch materials with spectroscopic techniques. J Appl Polym Sci 93:2650-2663. https://doi.org/10.1002/app.20851

Ding Y, Shen SZ, Sun H, Sun K, Liu F, Qi Y, Yan J (2015) Design and construction of polymerised-chitosan coated $\mathrm{Fe}_{3} \mathrm{O}_{4}$ magnetic nanoparticles and its application for hydrophobic drug delivery. Mater Sci Eng C Mater Biol Appl 48:487-498. https://doi.org/ 10.1016/j.msec.2014.12.036

dos Santos J-FR, Alvarez-Lorenzo C, Silva M, Balsa L, Couceiro J, Torres-Labandeira J-J, Concheiro A (2009) Soft contact lenses functionalized with pendant cyclodextrins for controlled drug delivery. Biomaterials 30:1348-1355. https://doi.org/10.1016/j. biomaterials.2008.11.016

Dumitriu S (1996) Polysaccharides in medicinal applications. Routledge, New York

Dumoulin Y, Alex S, Szabo P, Cartilier L, Mateescu MA (1998) Crosslinked amylose as matrix for drug controlled release. X-ray and FT-IR structural analysis. Carbohydr Polym 37:361-370. https:// doi.org/10.1016/S0144-8617(98)00058-7

El Ghoul Y, Blanchemain N, Laurent T, Campagne C, El Achari A, Roudesli S, Morcellet M, Martel B, Hildebrand HF (2008) Chemical, biological and microbiological evaluation of cyclodextrin finished polyamide inguinal meshes. Acta Biomater 4:1392-1400. https://doi.org/10.1016/j.actbio.2008.02.019

Ergoren MC, Paolacci S, Manara E, Dautaj A, Dhuli K, Anpilogov K, Camilleri G, Suer HK, Sayan M, Tuncel G, Sultanoglu N, Farronato M, Tartaglia GM, Dundar M, Farronato G, Gunsel IS, Bertelli M, Sanlidag T (2020) A pilot study on the preventative potential of alpha-cyclodextrin and hydroxytyrosol against SARS-CoV-2 transmission. Acta Bio-Medica: Atenei Parmensis 91(13-S):e2020022. https://doi.org/10.23750/abm.v91i13-S. 10817

Felméray I, Fenyvesi É, Neumark T, Takács J, Gerlóczy A, Szejtli J (1996) Effect of cyclodextrin bead polymer on wound healing. In: Proceedings of eighth international symposium cyclodextrins, pp 491-494. https://doi.org/10.1007/978-94-011-5448-2_108

Feng G, Ping W, Qin XX, Liu J, Zhu X (2015) Ionic-liquid-loaded $\beta$-cyclodextrin-cross-linked polymer solid-phase extraction for the separation/analysis of linuron in fruit and vegetable samples. Food Anal Methods 8:2315-2320. https://doi.org/10.1007/ s12161-015-0118-6

Fenyvesi E (1988) Cyclodextrin polymers in the pharmaceutical industry. J Incl Phenom 6:537-545. https://doi.org/10.1007/BF006 60751

Fenyvesi E, Shirakura O, Szejtli J, Nagai T (1984) Properties of cyclodextrin polymer as a tableting aid. Chem Pharm Bull 32:665-669

Fenyvesi É, Ujházy A, Szejtli J, Pütter S, Gan TG (1996) Controlled release of drugs from cyclodextrin polymers substituted with ionic groups. J Incl Phenom Mol Recognit Chem 25:185-189. https://doi.org/10.1007/BF01041566

Fenyvesi É, Puskás I, Szente L (2019) Applications of steroid drugs entrapped in cyclodextrins. Environ Chem Lett 17:375-391. https://doi.org/10.1007/s10311-018-0807-7

Fliszár-Nyúl E, Szabó Á, Szente L, Poór M (2020) Extraction of mycotoxin alternariol from red wine and from tomato juice with betacyclodextrin bead polymer. J Mol Liq 319:114180. https://doi. org/10.1016/j.molliq.2020.114180 
Friedman RB (1988) Controlled release agent for cetylpyridinium chloride. United States Pat. Off. 4774329

Friedman RB, Hedges AR, Black FL, Gottneid DJ (1989) Complexation of aromatic compounds with, and their release from, cyclomaltoheptaose-containing polymers, hydroxyethylcyclomaltoheptaose, and cyclomaltoheptaose. Carbohydr Res 192:283-289. https://doi.org/10.1016/0008-6215(89)85186-9

Fujiyoshi T, Carrez O, Imizcoz M, Zornoza A, Isasi JR (2019) Interpenetrated polymer networks of poly( $\beta$-cyclodextrin)and polyvinylpyrrolidone with synergistic and selective sorption capacities. Carbohydr Polym 219:105-112. https://doi.org/10.1016/j.carbp ol.2019.05.027

Furue M, Harada A, Nozakura S (1975) Preparation of cyclodextrincontaining polymers and their catalysis in ester-hydrolysis. J Polym Sci Polym Lett Ed 13:357-360. https://doi.org/10.1002/ pol.1975.130130608

García-Zubiri ÍX (2005) Sorption of naphthalenes in beta-ciclodextrin polymers. Ph.D. thesis, University of Navarra

Gidwani B, Vyas A (2015) A comprehensive review on cyclodextrin based carriers for delivery of chemotherapeutic cytotoxic anticancer drugs. Biomed Res Int 2015:198268. https://doi.org/10. $1155 / 2015 / 198268$

Gil ES, Li J, Xiao H, Lowe TL (2009) Quaternary ammonium $\beta$-cyclodextrin nanoparticles for enhancing doxorubicin permeability across the in vitro blood-brain barrier. Biomacromolecules 10:505-516. https://doi.org/10.1021/bm801026k

Gim S, Zhu Y, Seeberger PH, Delbianco M (2019) Carbohydrate-based nanomaterials for biomedical applications. Wiley Interdiscip Rev Nanomed Nanonbiotechnol 11(5):e1558. https://doi.org/10.1002/ wnan. 1558

Girek T, Shin DH, Lim ST (2000) Polymerisation of $\beta$-cyclodextrin with maleic anhydride and structural characterization of the polymers. Carbohydr Polym 42:59-63. https://doi.org/10.1016/ S0144-8617(99)00138-1

Gonzalez H, Hwang SJ, Davis ME (1999) New class of polymers for the delivery of macromolecular therapeutics. Bioconjugate Chem 10:1068-1074. https://doi.org/10.1021/bc990072j

Gonzalez-Gaitano G, Isasi J, Velaz I, Zornoza A (2016) Drug carrier systems based on cyclodextrin supramolecular assemblies and polymers: present and perspectives. Curr Pharm Des 23:411432. https://doi.org/10.2174/1381612823666161118145309

Gref R, Duchêne D (2012) Cyclodextrins as "smart" components of polymer nanoparticles. J Drug Deliv Sci Technol 22:223-233. https://doi.org/10.1016/S1773-2247(12)50033-X

Gref R, Amiel C, Molinard K, Daoud-Mahammed S, Sébille B, Gillet B, Beloeil J-C, Ringard C, Rosilio V, Poupaert J, Couvreur P (2006) New self-assembled nanogels based on host-guest interactions: characterization and drug loading. J Control Release 111:316-324. https://doi.org/10.1016/j.jconrel.2005.12.025

Haley RM, Gottardi R, Langer R, Mitchell MJ (2020) Cyclodextrins in drug delivery: applications in gene and combination therapy. Drug Deliv Transl Res 10:661-677. https://doi.org/10.1007/ s13346-020-00724-5

Harada A, Furue M, Nozakura SI (1977) Interaction of cyclodextrincontaining polymers with fluorescent compounds. Macromolecules 10:676-681. https://doi.org/10.1021/ma60057a036

Hirayama C, Kosugi Y, Motozato Y (1984) Studies on inclusion behaviors of $\beta$-cyclodextrin-starch composite gel by spin probe method. J Macromol Sci Part A Chem 21:1487-1492. https:// doi.org/10.1080/00222338408055677

Hoang Thi TH, Chai F, Leprêtre S, Blanchemain N, Martel B, Siepmann F, Hildebrand HF, Siepmann J, Flament MP (2010) Bone implants modified with cyclodextrin: study of drug release in bulk fluid and into agarose gel. Int J Pharm 400:74-85. https:// doi.org/10.1016/j.ijpharm.2010.08.035
Huang H, Tang G, Wang Q, Li D, Shen F, Zhou J, Yu H (2006) Two novel non-viral gene delivery vectors: low molecular weight polyethylenimine cross-linked by (2-hydroxypropyl)-betacyclodextrin or (2-hydroxypropyl)-gamma-cyclodextrin. Chem Commun (Camb) 600:2382-2384. https://doi.org/10. 1039/b601130f

Huang Y, Liu M, Chen J, Gao C, Gong Q (2012) A novel magnetic triple-responsive composite semi-interpenetrated network hydrogels for targeted and controlled drug delivery. Eur Polym J 48:1734-1744. https://doi.org/10.1016/j.eurpolymj.2012.06.012

Janus L, Crini G, El-Rezzi V, Morcellet M, Cambiaghi A, Torri G, Naggi A, Vecchi C (1999) New sorbents containing beta-cyclodextrin. Synthesis, characterization, and sorption properties. React Funct Polym 42:173-180. https://doi.org/10.1016/S13815148(98)00066-2

Kaji Y, Uekama K, Yoshikawa H, Takada K, Muranishi S (1985) Selective transfer of 1-hexylcarbamoyl-5-fluorouracil into lymphatics by combination of $\beta$-cyclodextrin polymer complexation and absorption promoter in the rat. Int J Pharm 24:79-89. https:// doi.org/10.1016/0378-5173(85)90145-0

Karadake K, Morimoto T, Tsuda K (1982) Japan Kokai 57-130914. Japan Kokai 57:130914

Kutyła MJ, Lambert LK, Davies NM, McGeary RP, Shaw PN, Ross BP (2013) Cyclodextrin-crosslinked poly(acrylic acid): synthesis, physicochemical characterization and controlled release of diflunisal and fluconazole from hydrogels. Int J Pharm 444:175-184. https://doi.org/10.1016/j.ijpharm.2013.01.005

Landy D, Mallard I, Ponchel A, Monflier E, Fourmentin S (2012) Remediation technologies using cyclodextrins: an overview. Environ Chem Lett 10:225-237. https://doi.org/10.1007/ s10311-011-0351-1

Larrañeta E, Stewart S, Ervine M, Al-Kasasbeh R, Donnelly RF (2018) Hydrogels for hydrophobic drug delivery. Classification, synthesis and applications. J Funct Biomater. https://doi.org/10.3390/ jfb9010013

Laurent T, Kacem I, Blanchemain N, Cazaux F, Neut C, Hildebrand HF, Martel B (2011) Cyclodextrin and maltodextrin finishing of a polypropylene abdominal wall implant for the prolonged delivery of ciprofloxacin. Acta Biomater 7:3141-3149. https://doi.org/10. 1016/j.actbio.2011.04.020

Lee KP, Choi SH, Ryu EN, Ryoo JJ, Park JH, Kim Y, Hyun MH (2002) Preparation and characterization of cyclodextrin polymer and its high-performance liquid-chromatography stationary phase. Anal Sci 18:31-34. https://doi.org/10.2116/analsci.18.31

Levack AE, Cyphert EL, Bostrom MP, Hernandez CJ, von Recum HA, Carli AV (2018) Current options and emerging biomaterials for periprosthetic joint infection. Curr Rheumatol Rep. https://doi. org/10.1007/s11926-018-0742-4

Li D, Ma M (1999) Nanosponges: from inclusion chemistry to water purifying technology. ChemTech 29:31-37

Li R, Jiang ZT, Wang RX (2009) Solid phase extraction combined direct spectrophotometric determination of brilliant blue in food using $\beta$-cyclodextrin polymer. Food Anal Methods 2:264-270. https://doi.org/10.1007/s12161-008-9065-9

Li M, Zhao M, Fu Y, Li Y, Gong T, Zhang Z, Sun X (2016) Enhanced intranasal delivery of mRNA vaccine by overcoming the nasal epithelial barrier via intra- and paracellular pathways. J Control Release 228:9-19. https://doi.org/10.1016/j.jconrel.2016.02.043

Li J, Wang X, Duan H, Wang Y, Bu Y, Luo C (2016a) Based on magnetic graphene oxide highly sensitive and selective imprinted sensor for determination of sunset yellow. Talanta 147:169-176. https://doi.org/10.1016/j.talanta.2015.09.056

Li Y, Lu P, Cheng J, Wang Q, He C (2018) Simultaneous solid-phase extraction and determination of three bisphenols in water samples and orange juice by a porous $\beta$-cyclodextrin polymer. 
Food Anal Methods 11:1476-1484. https://doi.org/10.1007/ s12161-017-1131-8

Liang G, Guo X, Tan X, Mai S, Chen Z, Zhai H (2019) Molecularly imprinted monolithic column based on functionalized $\beta$-cyclodextrin and multi-walled carbon nanotubes for selective recognition of benzimidazole residues in citrus samples. Microchem J 146:1285-1294. https://doi.org/10.1016/j.microc.2019. 02.064

Liu YY, Fan XD, Kang T, Sun L (2004) A cyclodextrin microgel for controlled release driven by inclusion effects. Macromol Rapid Commun 25:1912-1916. https://doi.org/10.1002/marc.20040 0396

Liu F, Zhang S, Wang G, Zhao J, Guo Z (2015) A novel bifunctional molecularly imprinted polymer for determination of Congo red in food. RSC Adv 5:22811-22817. https://doi.org/10.1039/c4ra1 $4719 \mathrm{~g}$

López-De-Dicastillo C, Jordá M, Catalá R, Gavara R, HernándezMuñoz P (2011) Development of active polyvinyl alcohol/ $\beta$ cyclodextrin composites to scavenge undesirable food components. J Agric Food Chem 59:11026-11033. https://doi.org/10. 1021/jf200749f

Luzardo-Alvarez A, Sobarzo-Sanchez E, Blanco-Mendez J, OteroEspinar FJ (2014) Cyclodextrin-based polysaccharidic polymers: an approach for the drug delivery. Curr Top Med Chem 14:542-551

Ma M, Li DQ (1999) New organic nanoporous polymers and their inclusion complexes. Chem Mater 11:872-874. https://doi.org/ $10.1021 / \mathrm{cm} 981090 \mathrm{y}$

Machín R, Isasi JR, Vélaz I (2012) $\beta$-Cyclodextrin hydrogels as potential drug delivery systems. Carbohydr Polym 87:2024-2030. https://doi.org/10.1016/j.carbpol.2011.10.024

Mäkelä M, Korpela T, Laakso S (1987) Colorimetric determination of $\beta$-cyclodextrin: two assay modifications based on molecular complexation of phenolphatalein. J Biochem Biophys Methods 14:85-92. https://doi.org/10.1016/0165-022X(87)90043-1

Martel B, Weltrowski M, Ruffin D, Morcellet M (2002) Polycarboxylic acids as crosslinking agents for grafting cyclodextrins onto cotton and wool fabrics: study of the process parameters. J Appl Polym Sci 83:1449-1456. https://doi.org/10.1002/app.2306

Martel B, Ruffin D, Weltrowski M, Lekchiri Y, Morcellet M (2005) Water-soluble polymers and gels from the polycondensation between cyclodextrins and poly(carboxylic acid)s: a study of the preparation parameters. J Appl Polym Sci 97:433-442. https://doi.org/10.1002/app.21391

McCormack B, Gregoriadis G (1994) Drugs-in-cyclodextrinsin liposomes: a novel concept in drug delivery. Int J Pharm 112:249-258. https://doi.org/10.1016/0378-5173(94)90361-1

Mejia-Ariza R, Graña-Suárez L, Verboom W, Huskens J (2017) Cyclodextrin-based supramolecular nanoparticles for biomedical applications. J Mater Chem B 5:36-52. https://doi.org/10. 1039/c6tb02776h

Mellet CO, Fernández JMG, Benito JM (2011) Cyclodextrin-based gene delivery systems. Chem Soc Rev 40:1586-1608. https:// doi.org/10.1039/C0CS00019A

Mizobuchi Y, Tanaka M, Shono T (1980) Preparation and sorption behaviour of cyclodextrin polyurethane resins. J Chromatogr A 194:153-161. https://doi.org/10.1016/S0021-9673(00)87291-X

Mocanu G, Vizitiu D, Carpov A (2001) Cyclodextrin polymers. J Bioact Compat Polym 16:315-342. https://doi.org/10.1106/ JJUV-8F2K-JGYF-HNGF

Moin A, Famna Roohi NK, Rizvi SMD, Ashraf SA, Siddiqui AJ, Patel M, Ahmed SM, Gowda DV, Adnan M (2020) Design and formulation of polymeric nanosponge tablets with enhanced solubility for combination therapy. RSC Adv 10:34869. https:// doi.org/10.1039/d0ra06611g
Morin-Crini N, Fourmentin S, Fenyvesi É, Lichtfouse E, Torri G, Fourmentin M, Crini G (2021) 130 years of cyclodextrin discovery for health, food, agriculture, and the industry: a review. Environ Chem Lett. https://doi.org/10.1007/ s10311-020-01156-w

Moya-Ortega MD, Alvarez-Lorenzo C, Concheiro A, Loftsson T (2012) Cyclodextrin-based nanogels for pharmaceutical and biomedical applications. Int J Pharm 428:152-163. https://doi. org/10.1016/j.ijpharm.2012.02.038

Nozaki T, Maeda Y, Ito K, Kitano H (1995) Cyclodextrins modified with polymer chains which are responsive to external stimuli. Macromolecules 28:522-524. https://doi.org/10.1021/ma001 $06 \mathrm{a} 016$

Oliveira MF, Suarez D, Rocha JCB, De Carvalho Teixeira AVN, Cortés ME, De Sousa FB, Sinisterra RD (2015) Electrospun nanofibers of polycyclodextrin/PMAA polymers and their potential application as drug delivery system. Mater Sci Eng C 54:252-261. https://doi.org/10.1016/j.msec.2015.04.042

Osmani RAM, Bhosale RR, Hani U, Vaghela R, Kulkarni PK (2015) Cyclodextrin based nanosponges: impending carters in drug delivery and nanotherapeutics. Curr Drug Ther 10:3-19. https:// doi.org/10.2174/157488551001150825095513

Palomino-Durand C, Lopez M, Cazaux F, Martel B, Blanchemain N, Chai F (2019) Influence of the soluble-insoluble ratios of cyclodextrins polymers on the viscoelastic properties of injectable chitosan-based hydrogels for biomedical application. Polymers (Basel). https://doi.org/10.3390/polym11020214

Peng L, Liu S, Feng A, Yuan J (2017) Polymeric nanocarriers based on cyclodextrins for drug delivery: host-guest interaction as stimuli responsive linker. Mol Pharm 14:2475-2486. https://doi.org/10. 1021/acs.molpharmaceut.7b00160

Petitjean M, García-Zubiri I, Isasi JR (2020) Cyclodextrin-based polymers for food and pharmaceutical applications: a historical review. In: Crini G, Fourmentin S, Lichtfouse E (eds) The history of cyclodextrins: environmental chemistry for a sustainable world, vol 52. Springer, Cham. https://doi.org/10.1007/ 978-3-030-49308-0_6

Piletsky SA, Andersson HS, Nicholls IA (1998) The rational use of hydrophobic effect-based recognition in molecularly imprinted polymers. J Mol Recognit 11:94-97. https://doi.org/10.1002/ (SICI)1099-1352(199812)11:1/6\%3c94::AID-JMR398\%3e3.0. $\mathrm{CO} ; 2-\mathrm{C}$

Pitha J, Harman SM, Michel ME (1986) Hydrophilic cyclodextrin derivatives enable effective oral administration of steroidal hormones. J Pharm Sci 75:165-167. https://doi.org/10.1002/jps. 2600750213

Plackett DV, Holm VK, Johansen P, Ndoni S, Nielsen PV, SipilainenMalm T, Södergård A, Verstichel S (2006) Characterization of L-polylactide and L-polylactide-polycaprolactone co-polymer films for use in cheese-packaging applications. Packag Technol Sci 19:1-24. https://doi.org/10.1002/pts.704

Pöpping B, Deratani A (1992) Synthesis of cyclodextrins with pendant chlorinated groups. Reaction of $\beta$-cyclodextrin with epichlorohydrin in acidic medium. Die Makromol Chemie Rapid Commun 13:237-241. https://doi.org/10.1002/marc.1992.030130409

Prabaharan M, Mano JF (2005) Hydroxypropyl chitosan bearing $\beta$-cyclodextrin cavities: synthesis and slow release of its inclusion complex with a model hydrophobic drug. Macromol Biosci 5:965-973. https://doi.org/10.1002/mabi.200500087

Qie S, Hao Y, Liu Z, Wang J, Xi J (2020) Advances in cyclodextrin polymers and their applications in biomedicine (in Chinese). Acta Chim Sin 78:232-244. https://doi.org/10.6023/A20010006

Renard E, Deratani A, Volet G, Sebille B (1997) Preparation and characterization of water soluble high molecular weight $\beta$-cyclodextrin-epichlorohydrin polymers. Eur Polym J 33:4957. https://doi.org/10.1016/S0014-3057(96)00123-1 
Reuscher H, Hirsenkorn R, Haas W (1998) Cyclodextrin derivatives having at least one nitrogen-containing heterocycle, their preparation and use. United States Pat. US 5728823

Řezanka M (2019) Synthesis of substituted cyclodextrins. Environ Chem Lett 17:49-63. https://doi.org/10.1007/s10311-018-0779-7

Romo A, Peñas FJ, Sevillano X, Isasi JR (2006) Application of factorial experimental design to the study of the suspension polymerisation of $\beta$-cyclodextrin and epichlorohydrin. J Appl Polym Sci 100:3393-3402. https://doi.org/10.1002/app.23778

Sarkar P, Choudhary R, Panigrahi S, Syed I, Sivapratha S, Dhumal CV (2017) Nano-inspired systems in food technology and packaging. Environ Chem Lett 15:607-622. https://doi.org/10.1007/ s10311-017-0649-8

Seidi F, Jin Y, Xiao H (2020) Polycyclodextrins: synthesis, functionalization, and applications. Carbohydr Polym 242:116277. https:// doi.org/10.1016/j.carbpol.2020.116277

Shaw PE, Buslig BS (1986) Selective removal of bitter compounds from grapefruit juice and from aqueous solution with cyclodextrin polymers and with Amberlite XAD-4. J Agric Food Chem 34:837-840. https://doi.org/10.1021/jf00071a018

Shaw PE, Tatum JH, Wilson CW (1984) Improved flavor of navel orange and grapefruit juices by removal of bitter components with $\beta$-cyclodextrin polymer. J Agric Food Chem 32:832-836. https://doi.org/10.1021/jf00124a034

Shende P, Deshmukh K, Trotta F, Caldera F (2013) Novel cyclodextrin nanosponges for delivery of calcium in hyperphosphatemia. Int J Pharm 456:95-100. https://doi.org/10.1016/j.ijpharm.2013.08. 012

Siemoneit U, Schmitt C, Alvarez-Lorenzo C, Luzardo A, Otero-Espinar F, Concheiro A, Blanco-Méndez J (2006) Acrylic/cyclodextrin hydrogels with enhanced drug loading and sustained release capability. Int J Pharm 312:66-74. https://doi.org/10.1016/j. ijpharm.2005.12.046

Simões SMN, Rey-Rico A, Concheiro A, Alvarez-Lorenzo C (2015) Supramolecular cyclodextrin-based drug nanocarriers. Chem Commun 51:6275-6289. https://doi.org/10.1039/c4cc10388b

Sofiane F, Lamia T, Mohamed S, Mokrane I-O (2020) The use of cyclodextrin or its complexes as a potential treatment against the 2019 novel coronavirus. A mini-review. Curr Drug Deliv 18:382. https://doi.org/10.2174/1567201817666200917124241

Solanki A, Das M, Thakore S (2018) A review on carbohydrate embedded polyurethanes: an emerging area in the scope of biomedical applications. Carbohydr Polym 181:1003-1016. https://doi.org/ 10.1016/j.carbpol.2017.11.049

Solms J, Egli RH (1965) Harze mit einschlusshohlraumen von cyclodextrin-struktur. Helv Chim Acta 48:1225

Specht M, Rothe M, Szente L, Szejtli J (1981) Removal of phenylalanine from protein hydrolysates. Ger. Offen. 147615

Sreenivasan K (1997) Absorption characteristics of a novel semi-interpenetrated network membrane based on $\beta$-cyclodextrin toward testosterone and progesterone. J Appl Polym Sci 64:1811-1814. https://doi.org/10.1002/(SICI)1097-4628(19970531)64:9\%3c181 1::AID-APP17\%3e3.0.CO;2-\#

Suh J, Hah SS, Lee SH (1997) Dendrimer poly (ethylenimine)s linked to beta-cyclodextrin. Biorgan Chem 25:63-75

Swaminathan S, Pastero L, Serpe L, Trotta F, Vavia P, Aquilano D, Trotta M, Zara GP, Cavalli R (2010) Cyclodextrin-based nanosponges encapsulating camptothecin: physicochemical characterization, stability and cytotoxicity. Eur J Pharm Biopharm 74:193-201. https://doi.org/10.1016/j.ejpb.2009.11.003

Szejtli J, Szente L (2005) Elimination of bitter, disgusting tastes of drugs and foods by cyclodextrins. Eur J Pharm Biopharm 61:115-125. https://doi.org/10.1016/j.ejpb.2005.05.006

Szejtli J, Fenyvesi E, Sarkoezi P, Felmeray I, Zsoldos A (1988) Cyclodextrin polymer/iodine inclusion compounds with controlled release of iodine. Ger. Offen. DE3819498A1
Szente L, Fenyvesi É (2018) Cyclodextrin-enabled polymer composites for packaging. Molecules 23:1556. https://doi.org/10.3390/molec ules23071556

Szente L, Puskás I, Sohajda T, Varga E, Vass P, Kristóf Nagy Z, Farkas A, Várnai B, Béni S, Hazai E (2021) Sulfobutylether-betacyclodextrin-enabled antiviral remdesivir: characterization of electrospun- and lyophilized formulations. Carbohydr Polym 264:118011

Szetjli J, Fenyvesi E, Zoltan S, Zsadon B, Tudos F (1979) Cyclodextrin-poly(vinyl alcohol) polymers in the form of beads, sheet, fibers or blocks. Hung. Pat. 19626; U. S. Pat. 4274985

Tabary N, Lepretre S, Boschin F, Blanchemain N, Neut C, DelcourtDebruyne E, Martel B, Morcellet M, Hildebrand HF (2007) Functionalization of PVDF membranes with carbohydrate derivates for the controlled delivery of chlorhexidin. Biomol Eng 24:472-476. https://doi.org/10.1016/j.bioeng.2007.07.007

Taha M, Chai F, Blanchemain N, Neut C, Goube M, Maton M, Martel B, Hildebrand HF (2014) Evaluation of sorption capacity of antibiotics and antibacterial properties of a cyclodextrin-polymer functionalized hydroxyapatite-coated titanium hip prosthesis. Int J Pharm 477:380-389. https://doi.org/10.1016/j.ijpharm.2014. 10.026

Tan S, Cui J, Fu Q, Nam E, Ladewig K, Ren JM, Wong EHH, Caruso F, Blencowe A, Qiao GG (2016) Photocontrolled cargo release from dual cross-linked polymer particles. ACS Appl Mater Interfaces 8:6219-6228. https://doi.org/10.1021/acsami.5b11186

Tanaka M, Mizobuchi Y, Kuroda T, Shono T (1981) Sorption behaviour of several organic compounds on 6-deoxycyclodextrin polyurethane resins. J Chromatogr A 219:108-112. https://doi.org/ 10.1016/S0021-9673(00)80579-8

Tanaka M, Kawaguchi Y, Nakae M, Mizobuchi Y, Shono T (1982) Separation of disubstituted benzene isomers on chemically bonded cyclodextrin stationary phases. J Chromatogr 246:207-214

Tian B, Liu Y, Jiayue Liu J (2020) Cyclodextrin as a magic switch in covalent and non-covalent anticancer drug release systems. Carbohydr Polym 242:116401. https://doi.org/10.1016/j.carbp ol.2020.116401

Tian B, Hua S, Liu J (2020) Cyclodextrin-based delivery systems for chemotherapeutic anticancer drugs: a review. Carbohydr Polym 232:115805. https://doi.org/10.1016/j.carbpol.2019.115805

Topuz F, Uyar T (2019) Electrospinning of cyclodextrin functional nanofibers for drug delivery applications. Pharmaceutics. https:// doi.org/10.3390/pharmaceutics11010006

Uekama K, Otagiri M, Irie T, Seo H, Tsuruoka M (1985) Improvement of dissolution and absorption characteristics of phenytoin by a water-soluble. Int J Pharm 23:35-42

Venter JP, Kotzé AF, Auzély-Velty R, Rinaudo M (2006) Synthesis and evaluation of the mucoadhesivity of a cyclodextrin-chitosan derivative. Int J Pharm 313:36-42. https://doi.org/10.1016/j.ijpha rm.2006.01.016

Wagner CJ Jr, Wilson CW III, Shaw PE (1988) Reduction of grapefruit bitter components in a fluidized $\beta$-cyclodextrin polymer bed. $\mathrm{J}$ Food Sci 53:516-518. https://doi.org/10.1111/j.1365-2621.1988. tb07745.x

Wang Q, Li S, Liu H, Zhang H, Li C (2009) The molecular inclusion function and $\mathrm{pH}$-sensitivity of hydrogel as a novel drug delivery system. J Drug Deliv Sci Technol 19:145-150. https://doi.org/ 10.1016/S1773-2247(09)50023-8

Wankar J, Kotla NG, Gera S, Rasala S, Pandit A, Rochev YA (2020) Recent advances in host-guest self-assembled cyclodextrin carriers: implications for responsive drug delivery and biomedical engineering. Adv Funct Mater 30:1909049. https://doi.org/10. 1002/adfm.201909049

Wei H, Yu CY (2015) Cyclodextrin-functionalized polymers as drug carriers for cancer therapy. Biomater Sci 3:1050-1060. https:// doi.org/10.1039/c4bm00417e 
Weickenmeier M, Wenz G (1996) Cyclodextrin sidechain polyesterssynthesis and inclusion of adamantan derivatives. Macromol Rapid Commun 17:731-736

Wiedenhof N, Lammers JNJJ, van Panthaleon Van Eck CL (1969) Properties of cyclodextrins part III. Cyclodextrin-epichlorhydrin resins: preparation and analysis. Starch Stärke 21:119-123. https://doi.org/10.1002/star.19690210504

Yang YC, Mei XW, Hu YJ, Su LY, Bian J, Li MF, Peng F, Sun RC (2019) Fabrication of antimicrobial composite films based on xylan from pulping process for food packaging. Int J Biol Macromol 134:122-130. https://doi.org/10.1016/j.ijbiomac.2019.05. 021

Yao H, Ng SS, Tucker WO, Tsang YKT, Man K, Wang X, Chow BKC, Kung HF, Tang GP, Lin MC (2009) The gene transfection efficiency of a folate-poly(ethyleneimine)600-cyclodextrin nanopolymer. Biomaterials 30:5793-5803. https://doi.org/10.1016/j. biomaterials.2009.06.051

Yao X, Huang P, Nie Z (2019) Cyclodextrin-based polymer materials: from controlled synthesis to applications. Prog Polym Sci 93:1-35. https://doi.org/10.1016/j.progpolymsci.2019.03.004
Zemel H, Koch MB (1990) Preparation of crosslinked cyclodextrin resins with enhanced porosity. United States Pat. Off. 4958015

Zhang JT, Huang SW, Gao FZ, Zhuo RX (2005) Novel temperaturesensitive, $\beta$-cyclodextrin-incorporated poly $(\mathrm{N}$-isopropylacrylamide) hydrogels for slow release of drug. Colloid Polym Sci 283:461-464. https://doi.org/10.1007/s00396-004-1224-y

Zhang J-T, Xue YN, Gao F-Z, Huang SW, Zhuo RX (2008) Preparation of temperature-sensitive poly(N-isopropylacrylamide $) / \beta$ cyclodextrin-grafted polyethylenimine hydrogels for drug delivery. J Appl Polym Sci 108:3031-3037. https://doi.org/10.1002/ app. 27931

Zhang D, Lv P, Zhou C, Zhao Y, Liao X, Yang B (2019) Cyclodextrinbased delivery systems for cancer treatment. Mater Sci Eng C 96:872-886. https://doi.org/10.1016/j.msec.2018.11.031

Publisher's Note Springer Nature remains neutral with regard to jurisdictional claims in published maps and institutional affiliations. 